Critical Inquiry in Language Studies

\title{
Intercultural Orientations as Japanese Language learners' Motivation in Mainland China
}

\begin{tabular}{|r|l|}
\hline Journal: & Critical Inquiry in Language Studies \\
\hline Manuscript ID & HCIL-2016-0012.R2 \\
\hline Manuscript Type: & Original Article \\
\hline Keywords: & Cross-Cultural Communication, Motivation, Politics, Attitude \\
\hline Abstract: & $\begin{array}{l}\text { This paper reports on a study that investigated how 665 Japanese } \\
\text { language learners, who had started learning Japanese at different times in } \\
\text { the last three decades, had been motivated to learn Japanese in China. } \\
\text { Analysis of the survey data revealed that the participants displayed similar } \\
\text { intercultural orientations when learning Japanese despite the shifting Sino- } \\
\text { Japanese relations and the massive anti-Japanese protests in mainland } \\
\text { China in recent years. In addition, the participants' qualitative comments in } \\
\text { the survey revealed that most of them could be regarded as dialogic } \\
\text { communicators who became interested in learning more about Japanese } \\
\text { culture, people and society after learning Japanese. These findings confirm } \\
\text { the critical role that learning a foreign language plays in promoting better } \\
\text { intercultural dialogue and sustaining goodwill among language learners } \\
\text { towards the target community. }\end{array}$ \\
\hline
\end{tabular}




\section{Intercultural Orientations as Japanese Language learners' Motivation in Mainland China}

Leining Lv, Faculty of Foreign Languages, Shanghai University of Finance and

Economics, Email address: 1v.leining@mail.shufe.edu.cn

Xuesong (Andy) Gao*, Faculty of Education, The University of Hong Kong, Email

address: xsgao@hku.hk

Timothy Teo, Faculty of Education, University of Macau, Email address:

TimothyTeo@umac.mo

* Corresponding author 


\section{Abstract}

This paper reports on a study that investigated how 665 Japanese language learners, who had started learning Japanese at different times in the last three decades, had been motivated to learn Japanese in China. Analysis of the survey data revealed that the participants displayed similar intercultural orientations when learning Japanese despite the shifting Sino-Japanese relations and the massive anti-Japanese protests in mainland China in recent years. In addition, the participants' qualitative comments in the survey revealed that most of them could be regarded as dialogic communicators who became interested in learning more about Japanese culture, people and society after learning Japanese. These findings confirm the critical role that learning a foreign language plays in promoting better intercultural dialogue and sustaining goodwill among language learners towards the target community.

Keywords: Cross-cultural communication, motivation, politics, attitude 
Introduction

Increasing cross-border movements of goods, ideas and people are supposed to lead to better mutual understanding among people across national and cultural boundaries. However, though "the tightly knit system of communication and transportation ... diminish physical boundaries," they also "exacerbate ethnic and national rivalries, rendering the deeply fractious and unsettling landscape... [and] galvanising many into 'us-against-them' posturing” (Kim, 2006, pp. 283-284). In many contexts, rising popular nationalistic sentiments have become a genuine, serious concern, requiring concerted efforts to examine the roots and identify possible solutions. One such possible solution relates to a long-standing notion about the role of language learning in promoting better intercultural understanding and social cohesiveness (e.g. Gardener, 1985; Holmes, 2014). The learning of a foreign language can be instrumental in promoting grass roots diplomacy which involves individual citizens engaging in intercultural dialogues for mutual understanding and may help neutralize the impact of popular nationalism on mutual exchanges (e.g. Donitsa-Schmidt, Inbar \& Shohamy, 2004; Holmes, 2014; Yun \& Kibber, 2012). This seems to be particularly important in the East Asian context, where major countries like China and Japan are apparently on a dangerous collision course over island disputes and historic memories of the Sino-Japanese War (1937-1945) (Reilly, 2014; Sinkkonen, 2013; Sneider, 2013). In light of the rising tensions between the two countries, this paper reports on an inquiry that examined Japanese language learners' intercultural orientations or their desire to know more about the target language community (e.g. the people and culture) in mainland China. By doing so, the study explored how they 
were motivated to learn Japanese at the time when they started learning it; they had started at different times in the last three decades.

Despite the rapprochement China and Japan had after normalization of diplomatic relations in

the 1970s, there have been major waves of anti-Japanese protests in the 1980s, 1990s and 2000s (e.g. Cui,

2012; Reilly, 2014). In particular, after the appeal of the communist ideology collapsed in the 1990s, the

Chinese government decided to strengthen patriotic education to rekindle the love for the country and the state (e.g. Zhao, 1998). China's defeats in wars with foreign aggressors including Japan were highlighted in such patriotic education to mobilize individual Chinese for the better cause of the nation (e.g. Tang \& Darr, 2012; Zhao, 1998). In the new millennium, Japanese government leaders' visits to the Yasukuni shrine, which enshrines 14 A-class war criminals held responsible for Japan's wartime conduct during the Second World War, and the territorial dispute in East China sea led to a massive outbreak of antiJapanese protests in 2005 (e.g. Cui, 2012; Reilly, 2014). The 2005 protest is usually considered a landmark event as it was associated with the open and unconstrained expressions of popular nationalism at an unprecedented level (e.g. Ching, 2012; Sinkkonen, 2013). In the last 10 years, the Sino-Japanese political and diplomatic relationship has been constrained by this growing anti-Japanese sentiment, which has led to diplomatic rows over a boat collision in 2010 and further protests in 2012 (e.g. Cui 2012; Reilly 2014). However, the number of Japanese language learners in China has kept growing. According to Japan Foundation, China had the largest number of Japanese language learners (1.046 million out of 3.985 million Japanese language learners worldwide) in 2012, a $26.5 \%$ rise since 2009 . One may wonder 
what has been attracting these learners in the last three decades. An inquiry into these learners'

motivation to learn Japanese is expected to provide important insights into the relationship between

language learning and cross-cultural understanding. It addresses a critical question as to whether a

growing number of Japanese language learners constitute a solid foundation for sustainable intercultural

dialogues in light of the rising tensions between the two countries.

\section{Language Learning Motivation and Intercultural Orientation}

Different conceptualizations have been proposed to theorize the construct of the motivation underlying

individuals' efforts to learn foreign languages. Most of these involve positioning of individual language

learners in relation to the relevant societies or imagined communities speaking the target language (e.g.

Dörnyei, 2005; Dörnyei \& Ushioda, 2009; Gardner, 1985; Ryan, 2006). Recent research has largely

focused on how the learning of foreign languages helps learners realize a complex self-system (e.g.

Dörnyei \& Ushioda, 2009; Ryan, 2006). These studies regard target language competence as an attribute

that enables learners to claim what they ideally want to be, ought to be or actually are. While such

theorisation of motivation develops notions of target language competence in relation to individual

learners' self (i.e. desires, expectations and so on), it does not negate the profound impact that an

increasing number of individuals speaking a particular foreign language could possibly have on the

society. Though it may be a sort of over simplification of conceptualization of language learners'

motivation in terms of desires and wishes to integrate into target language speakers' community, the

learning of foreign languages does help individuals overcome linguistic barriers when fostering mutual 
cross-cultural understanding; the desire for better cross-cultural understanding may also orient their efforts to learn foreign languages (e.g. Humphreys \& Miyazoe-Wong, 2007; Sugita-McEown Noels \& Saumure, 2014). Gao (2014) identifies four types of language learners: those who 1) faithfully imitate target language speakers' language use; 2) claim legitimacy as target language users; 3) creatively use target languages for self-expression; and 4) engage with target language speakers in dialogic communication for mutual understanding in the learning process. She (2014) argues that language learners as "dialogical communicators", probably the most ideal language learners, have "particular implications for future [language] education targeted at intercultural competence and intercultural citizenship" (p. 73). Individual language learners may develop some sense of affinity towards the communities of target language speakers for sustained intercultural dialogues and cross-cultural understanding (Donitsa-Schmidt et al., 2004; Holmes, 2014). Therefore, it can be argued that such intercultural orientations are important for sustaining efforts to learn foreign languages (e.g. Gao, 2014; Yashima, 2002).

The concept of intercultural orientation draws on Yashima's (2002) research on English language learners 'international posture' in Japan, which includes their 'interest in foreign or international affairs, willingness to go overseas to stay or work, readiness to interact with intercultural partners and openness... toward different cultures' (p. 57). By addressing intercultural 'friendship and vocational interest', this notion of international posture reconciles the dichotomy between integrative (i.e. learning a language because of some personal affinity with target language speakers) and instrumental (i.e. learning 
a language for practical reasons such as employment) motivations, which was then a prevalent way to conceptualise motivation (ibid). Yashima and colleagues have further explored how contextual conditions and processes have influenced Japanese high school students' willingness to communicate in English and their international postures (Yashima \& Zenuk-Nishide, 2008). They conclude that "students who studied abroad came to acquire a higher level of international posture, that is, they have a stronger intergroup approach tendency, interest in international vocations, activities and international affairs” (p. 580). In light of Yashima's (2002) conceptualization of international postures, this study explores Chinese language learners' intercultural orientations as motivation to learn Japanese, which include intercultural exchange and understanding as reasons to learn Japanese, the readiness to interact with Japanese people, interest in Japan-related cultural products, vacations and activities as well as interest in other Japanrelated affairs.

Previous research on Japanese language learners' motivation in Hong Kong (Humphreys \& Miyazoe-Wong, 2007) suggests that these learners were largely attracted to learn Japanese by Japanese popular culture while political rows between China and Japan apparently had no impact on their motivation to learn the language. However, it must be noted that socio-political conditions in Hong Kong are very different from those in Mainland China, where nationalism has been instrumental in sustaining the political status quo (e.g. Zhao, 1998). In Mainland China, the state-controlled mass media has frequently reported on ongoing clashes between China and Japan and the Sino-Japanese war has become a favored topic in the TV and film industry. For instance, over 150 series of TV dramas on the Sino- 
Japanese War were released during 1949-2004 while 20 series were produced in 2005 alone and the

figure reached 70 in 2012 (Lin, 2013). In the meantime, Relic sites associated with the Sino-Japanese war have been enshrined as bases for national education. In September 2015 instead of the National Day, the Chinese government had a military parade to celebrate the Imperial Japanese armed forces' surrender or the end of the Second World War (Tiezzi, 2015). These contextual differences, together with the rising number of Japanese language learners in Mainland China, makes it necessary to examine how Japanese language learners have been motivated to learn Japanese over the last three decades, with a focus on intercultural orientations as an important component of language learning motivation.

\author{
The Study \\ The study explored the motivation in terms of intercultural orientations of Japanese language learners \\ who had started learning the language at different times in the last three decades. The researchers \\ addressed the following questions:
}

1) Are there differences in intercultural orientations of participants who started learning Japanese at different times in the last few decades?

2) In what ways are these differences or similarities in the participants' intercultural orientations related to background factors like duration of learning Japanese and exposure to Japanese culture (e.g. visits to Japan)? 
participants and interviews of 38 surveyed participants who started learning Japanese at different times in the last three decades.

\section{Participants}

This study examined participants who started learning Japanese in the 1980s, 1990s and 2000s.

Participants were current students, graduates and teachers in Faculty of Foreign Languages or Department of Japanese Studies at universities based in southern Chinese cities. Since these universities recruit students across the nation, these participants are also from different parts of China.

As can be seen in Table 1, most participants (552 out of 665) were female and over half (342)

had been learning Japanese for one to two years while 162 had learnt Japanese for 2 to 5 years. Another 151 indicated that they had learnt Japanese for over 5 years. The majority of them (429) were university students, including undergraduates and postgraduates majoring in Japanese language and literature and 69 Japanese language teachers. Among the participants, most (482) had never been to Japan but nearly a quarter (151) had been to the country.

\section{Insert Table 1 here}

\section{Instrument}

The survey instrument consisted of two sections. In the first section, the survey asks about participants' personal backgrounds, including the time when the respondent started learning Japanese, the circumstances at that point of time, duration of learning Japanese, and frequency of visiting Japan. It also 
asks whether they had changed their overall impressions of Japan. For the sake of brevity, the questionnaire does not fully elaborate what 'Japan' means. For this reason, the participants were encouraged to explain what their overall impressions were like, why they visited Japan (if they had been to Japan) and why they had changed their impressions in the open ended questions of this section. The second section was an 18-item questionnaire survey exploring participants' intercultural orientations from four dimensions (Yashima, 2002) (Table 2). The participants were asked to respond to the 18 items using a seven-point Likert scale ranging from 1 (strongly disagree) to 7 (strongly agree).

The questionnaire was adapted from items on Japanese students' international postures in Yashima (2002) which cover statements taken in the course of intercultural communication research, including those on approach-avoidance and ethno-centrist tendency. The questionnaire has four dimensions (see Table 2). Dimension 1 evaluates Japanese language learners' intercultural exchange and understanding as reasons to learn Japanese ('Intercultural exchange and understanding as reasons to learn Japanese' or 'Intercultural exchange'). It includes statements asking the participants to what extent they had been motivated by the desire to understand the country, people and culture better. Dimension 2 includes statements originally developed on the basis of Yashima's (2002) avoidance-approach ('Readiness to interact with Japanese people' or 'readiness'). Since the participants were found to have responded to the statements on the avoidance tendency with low reliability, Dimension 2 has items only on the participants' readiness to interact with Japanese people. Dimension 3 is about the participants' interest in Japan-related cultural products, vocations ('Willingness to take up/use Japan-related activities, 
products and vocations' or 'Willingness'). It invites the participants to evaluate how willing they are to work in Japanese companies, attend Japan-related cultural activities and travel to Japan as tourists.

Dimension 4 is concerned with how active and interested the participants are in learning about what happens in Japan ('Interest in Japan-related affairs' or 'Interest'). The Cronbach alpha reliability results of the formal study were .92 in general and $.89, .84, .71$ and .78 for the four dimensions, respectively.

\section{Insert Table 2 here}

\section{Data Collection and Analysis}

The data were collected through the researchers' contacts in Japanese language departments in major universities in southern Chinese coastal cities and our personal contacts who were known to have learnt Japanese. Students in universities were sent the questionnaire in a MSWORD file and were asked to return the completed questionnaires back to their Japanese language teachers or directly to us. Other participants were also sent the questionnaire through email and were asked to return the completed questionnaires directly to us. Only on a few occasions did the researchers sit with the participants and oversaw completion of the questionnaire. The questionnaire was administered in Chinese, the language most familiar to researchers as well as participants. Participation was entirely voluntary and no incentives were given to the surveyed participants.

Data were analysed using descriptive and inferential statistics for the background information survey items. One-way ANOVA was conducted to test for possible mean differences between participants' intercultural orientations and background variables. Chronbach alpha level of .05 was used to determine 
statistical significance for all tests in the study. The participants' answers to the open-ended questions concerning their impressions of Japan were coded to provide qualitative comments in support of the intercultural orientations while their comments on why they had (not) changed their perceptions and attitudes were analysed to gain insights into their intercultural orientations (e.g. Patton, 1990). These comments help better appreciate any differences or similarities identified in the statistical analysis. Two coders went through the data and identified 33 themes in the comments together with 18 reasons the participants cited to explain why their impressions of Japan had or had not changed. Since most participants wrote brief answers to the questions, the two coders were able to have a high rate of interrater agreement with Pearson's $r=0.9959$. Statistical findings are reported before the participants' answers to the open-ended questions.

\section{The Findings}

Despite the shifting Sino-Japanese relations and massive anti-Japanese protests in recent years (e.g. Cui, 2012; Reilly, 2014), this study did not find any statistically significant variations in intercultural orientations of participants who had started learning the language at different times; the participants' intercultural orientations were found to be quite stable across the learners.

\section{The Participants' Intercultural Orientations}

One-way ANOVA tests were run to examine differences in intercultural orientations among the three different learning groups, that is, those who had started learning Japanese in the 1980s, 1990s and post2000. No statistical differences were found in the intercultural orientations (Table 3). In Dimension 1 
('Intercultural exchange') $F(2,656)=.25, p=.78$; Dimension 2 ('Readiness'), $F(2,659)=.50, p=.61$; and

Dimension 4 ('Interest'), $F(2,656)=2.33, p=.10$. Statistically significant difference was found only in

Dimension 3 ('Willingness'), $F(2,659)=3.78, p=.02$. Scheffe's post hoc procedure indicates that

participants who had started learning Japanese in the 1990s $(M=5.53, S D=1.01)$ had significantly lower

willingness to live or work in Japan than those who had started learning Japanese in the new century ( $M$

$=5.82, S D=.86), p<.05, d=.30$.

\section{Insert Table 3 here}

A total of 539 participants had started learning Japanese in the 2000s; participants in the 2000s

cohort were further divided into groups at 5 year intervals, punctuated by major anti-Japanese protests

and significant Sino-Japanese diplomatic incidents in 2005 and 2012. The analysis revealed no

statistically significant differences in intercultural orientations in any of the four dimensions, Dimension

1 ('Intercultural exchange'), $F(2,631)=.96, p=.43$; Dimension 2 ('Readiness') $, F(2,634)=.72, p=.58$;

Dimension 3('Willingness'), $F(2,634)=2.18, p=.07$; and Dimension 4 ('Interest'), $F(2,634)=1.34$,

$p=.22$. This means that intercultural orientations, irrespective of when they started learning Japanese

(earlier or late), remained stable among all participants. In other words, motivations of most of the

participants were apparently not affected by increasing Sino-Japanese tensions and the massive

outpouring of popular nationalist sentiments (e.g. Humphreys \& Miyazoe-Wong, 2007).

To further appreciate participants' intercultural orientations, statistical analysis was undertaken to explore the connection between intercultural orientations and background factors, including the 
circumstances for learning Japanese, durations of learning Japanese and number of visits to Japan. Firstly, intercultural orientations of participants with different circumstances were found to be significantly different; participants included Japanese major students, non-major Japanese language learners, Japanese major graduates who worked in Japanese companies, Japanese major graduates who worked in nonJapanese companies and Japanese language teachers. One-way ANOVA tests indicated significant differences among participants having different circumstances (Table 5), $F(4,652)=4.73, p=.000$ and the differences existed in all four dimensions: Dimension $1, F(4,652)=3.81, p=.002$; Dimension $2, F(4$, $655)=3.82, p=.002$; Dimension $3, F(4,655)=5.86, p=.000 ;$ and Dimension $4, F(4,655)=3.81, p=.02$. The Scheffe's post hoc analysis revealed that Japanese major students ( $\mathrm{n}=429, M=5.79, S D=.726)$ had much more positive intercultural orientations towards Japan than non-Japanese major students ( $\mathrm{n}=74, M$ $=5.40, S D=.717),(p=.004, d=.54)$.

\section{Insert Table 4 here}

Second, duration of Japanese learning experience was found to have been an important factor related to intercultural orientation. Different durations of Japanese learning experiences apparently had no significant correlation with general intercultural orientations among participants with 1-2, 2-5 and over 5 years of Japanese learning experiences, $F(2,655)=1.24, p=.29$. The results of Scheffe's post hoc procedure suggest that those who had learnt Japanese for 2-5 years $(M=5.83, S D=.93)$ displayed statistically significantly lower readiness to interact with Japanese people than those who had learnt Japanese for over 5 years $(M=6.06, S D=.77)$. Those who had learnt Japanese for 2-5 years were also 
found to have lower interest in Japan-related affairs $(M=5.12, S D=.95)$ than those who had learnt it for more than 5 years $(M=5.37, S D=.88)$.

\section{Insert Table 5 here}

Likewise, the participants' visits to Japan were also found to be relevant to their intercultural

orientations (Table 7). Independent $\mathrm{t}$ tests revealed that there were significant differences $(p=.023)$ between participants who had no experience of visiting Japan $(M=5.67, S D=.75)$ and those who had such experiences $(M=5.83, S D=.73)$, and the attitudes of the two cohorts of participants towards Japan were significantly different in terms of Dimension $2(p=.009)$ and Dimension $4(p=.008)$. However, no significant differences $(p=.023)$ were found between participants who had visited Japan only once $(M$ $=5.88, S D=.78)$ and those who had visited Japan more than once $(M=5.77, S D=.66)$.

\section{Insert Table 6 here}

These statistical results suggest that those who display positive intercultural orientations are usually those who had in-depth and extended engagement with the Japanese language, culture and people (e.g. Gardner, 1985; Sugita-McEown et al., 2014). Such results were further supported by the qualitative data gathered in the survey.

\section{Understanding the Participants' Intercultural Orientations}

Participants' answers to the first open ended question, which most participants answered in brief, reflect highly positive impressions of Japan, including its culture, environment, people and society. Echoing the statistical findings, 405 participants, including 257 participants who had never been to Japan, made 
positive-only comments. These comments reveal why participants were interested in learning more about the target language speakers' community. In contrast, only a small number of negative comments were made on Japan's culture and politics. None of these participants had been to Japan.

Japan's natural environment received the largest number of positive comments. 302 participants (45.41\%) praised the environment in Japan and also the ways the environment was preserved in the country. These comments described Japan as a "clean" (151 times), “beautiful” (69 times), “delicate” (14 times), "safe" (9 times), "comfortable" (2 times) and "lovely" (4 times) country. They lauded the country's efforts to preserve environment, many specifically mentioning "the rubbish classification system" as an example of the country's dedication to preservation of environment. In addition, they also appreciated that Japan has a nice and safe physical environment for people. A participant who had learnt Japanese for 20 years commented after visiting Japan:

The environment of Japan is even better than I thought and Japanese people have strong awareness of environment protection.

Underlying this comment is a realization that the "nice" and "safe" environment depends on people's commitment to preserve it. Consequently, it is not surprising that the participants made favourable comments on Japanese people. Analysis of the data helped identify 271 positive comments on people, which portray them as “well-mannered” (108 times), “serious” (48 times), "hardworking” (28 times), "humble" (5 times), "friendly but boring”, "self-disciplined”, “caring” and so on. A female 
Japanese teacher who had been in Japan for 8 years recorded the following observation on Japanese people when answering the question:

Japanese people are friendly and hospitable. They are meticulous and responsible about their work. They tend to be very considerate when dealing with people, using implicit and euphemistic language to avoid hurting others' feelings...

The appeal of the country to these participants was also related to Japan's social development.

The participants made over 173 positive comments on Japan's society and projected it favorably in terms of modernization and technological advances. These participants believed that the Japanese society is an "advanced", “orderly", "highly civilised", “economically developed”, "well-governed”, "convenient” and "open". In their perceptions, the country provides "first class service", "social benefits", "good facilities" and "high quality education" to its residents.

Like their comments on protection of environment, 48 participants admired Japanese people's commitment to conserving cultural heritage. A male Japanese teacher who had visited Japan 4 times during 1995-2008 noted:

[In Japan], historic buildings are well protected. You can sense the charming flavor from the ancient architecture: shrines and temples under some old, towering trees... The

Japanese culture is visible.

The participants also perceived Japan as a culturally inclusive and diverse country. A female participant who needs to use Japanese at her workplace contends that Japanese people "not only put great 
emphasis on their own cultural heritage but are also amazingly inclusive towards diverse (foreign)

cultures." Another female who started her Japanese studies in 2013 also echoed this view, saying "[Japan

holds] a rich vein of its own culture, and it is culturally inclusive."

Analysis of answers to other open-ended questions revealed that participants' impressions of

Japan were mediated by a host of agents including teachers, peers and Japanese friends through a variety

of activities including language learning, cultural appreciation, travel and socialization. One participant,

who had never been to Japan, reflected on his changing impressions of Japan as follows:

Before I learnt Japanese, I had no particular impressions about the country. When I thought

of the country, I thought about the Sino-Japanese war and then anime. After I learnt

Japanese, I became more and more knowledgeable about the country. Through my contacts

with the Japanese, I began to feel the magic of the country.

Likewise, another participant who discovered, after socialising with Japanese people, that "there

are many kinds of Japanese who are willing to help others." Such discoveries are highly significant as

some of the deep-rooted biases get dissolved after one has a better understanding of the country and its

people.

The participants also started questioning their previous perceptions of the country and their

understanding of history also enabled them to see the relationships between the two countries from a new

perspective: 
Since I know more about Japan now, I am in a position to look at this country from a

different perspective. I no longer follow ready-made opinions, such as those in the history

textbooks. It is natural for a country to have pros and cons. A university student should not

adopt a one-sided approach.

The data extract suggests that the particular learner can be regarded as a "dialogic

communicator", who has "a reflective sensitivity, ready to discern, expand, deepen and reorganise various

kinds of consciousness within him- or herself" (Gao, 2014, p.68). Careful examination of the participants'

answers also helped identify that these positive changes were induced by the participants' interactions

with teachers, peers and Japanese cultural products. Since a large number of participants are or used to be

university students, Japanese language teachers were found to have played a key role in fostering positive

perceptions about Japan among them. A Year 4 university student explained why he changed his

perceptions of the country as follows:

I now know more about the country. Teachers give me a lot of positive information about it.

In the past, I only had hatred but I have now discovered that Japan is quite loveable.

The participants also admitted that they had "improved [their] feelings about Japan" "with the

help of my Japanese teacher." One participant even mentioned that he "had only hatred toward that

country" before the teacher introduced him to "the bright side of Japan." Peers were also found to have

influenced the participants' intercultural orientations. One participant noted that she changed her 
impressions because her classmates who had been to Japan commented highly positively about the country, as follows:

All my classmates who went to Japan were talking about how wonderful that country is.

My impression about it has become much better.

Such positive impressions were followed by the participants' escalated motivation to learn

Japanese and even visit the country. The data also suggest that the participants' positive impressions have been sustained by their love for Japanese cultural products including anime and popular culture. These cultural products have also motivated the participants to learn the language and develop increasingly positive impressions. One anime lover wrote in the survey:

I changed my perceptions because I became appreciative of some of the beautiful cultural products from Japan. I realized that it really stresses the importance of humanity. The more anime I read, I can feel more the spirits of being strong, brave and selfless among anime figures. This must have something to do with the authors!

Other participants believed that exposure to Japanese culture had helped them learn to appreciate Japanese people and become "much more positive about [their] behavior, lifestyles and thinking approach." Another student claimed that he had learnt from the traditional rituals and customs of Japan, which helped "understand the rationale behind their behaviors." All these comments suggest that the learning of Japanese has prepared a solid foundation for intercultural dialogue, which in turn generates 
motivation for them to learn the language and acquire better cross-cultural understanding (e.g. Holmes, 2014; Yun \& Kibber, 2012).

However, 36 participants referred to specific problems such as history textbooks, Japan's war

crimes, the country's unwillingness to respect history and rightists still harboring imperial designs. It

must be noted that these problems do not necessarily discourage the participants from admiring the

country after getting to know more about it. Only 23 participants mentioned that recent political situations

had discouraged them from displaying overtly positive impressions about the country (e.g. Ching, 2012;

Cui, 2012; Reilly, 2014). One who had started studying Japanese in 2006 (right after the anti-Japanese

protests) shared his feelings after a brief journey to Japan:

During a hasty trip I experienced the real Japan. On the return flight I could not help but reflect upon what I had seen and heard. From the Japanese people I encountered, no enmity

was sensed at all. On the contrary, I felt their kindness, friendliness, politeness and gentleness. [...] The Japanese society is healthy and harmonious with its senior citizens and adults and children taken good care of. People lead a free, equal, happy and peaceful life there. [...], we should learn from them.

This participant's experience testifies the importance of in-depth, meaningful engagement with Japanese people and its effect on the participants' intercultural orientations in learning Japanese (e.g. Donitsa-Schmidt et al., 2004; Gardner, 1985). The qualitative comments that the participants made in the survey suggest that those who have been to Japan usually had an enhanced readiness to socialise with 
Japanese people and heightened interest in learning more about the country. In many cases, collective consciousness as acquired through media and community sources of information may be much stronger in cases where people have no personal experience with a target culture. The results of this study suggest that contact with culturally different others (whether through travel or language study alone) trumps negative attitudes encouraged by social milieu.

\section{Discussion}

At the outset of the study, we intended to explore what attracts the Chinese to learn Japanese despite the increasingly negative media coverage in China. Though we speculated that ongoing tensions between the two countries concerning the Sino-Japanese War might have mediated the participants' intercultural orientations and in turn motivation to learn Japanese, participants who had started learning Japanese in the 1980s, 1990s and 2000s displayed quite stable intercultural orientations. Even during two major outbursts of anti-Japanese demonstrations in 2005 and 2012, those who had started learning Japanese still displayed positive intercultural orientations. The participants' qualitative comments add further support to the statistical finding that intercultural orientations remain largely positive. Both qualitative and quantitative data suggest that the more time the participants had spent learning Japanese and the deeper was the engagement they had with Japanese people and culture, the more favorable their intercultural orientations are. These findings confirm those of a study on Japanese language learners' motivation in Hong Kong (Humphreys \& Miyazoe-Wong, 2007), but the issue deserves further commentary considering the rising tensions between the two countries. 
Despite increased negative media coverage of diplomatic tensions and bitter historical memories,

most participants (405 out of 665) made positive comments on Japan in terms of its environment, people

and social development. That 302 participants lavished praise on Japan's “clean" environment and

environmental consciousness might have something to do with the fact that China is having serious

problems of environmental pollution and many participants were genuinely impressed by the "clean"

environment in Japan, which they desired to have in China. Participants overall disposition was also

mediated by various cultural artefacts (e.g. Manga from Japan) and favorable intercultural orientations

even though they had been bombarded with anti-Japanese war TV dramas. These findings suggest that

participants can be regarded as dialogic communicators, who are willing and ready to engage in

intercultural dialogues for better mutual understanding through learning Japanese (Gao, 2014; Holmes,

2014). They confirm that participants do not "lend [themselves] easily to programmed training or testing"

but they rely on "sustained personal commitment and gradual maturation" in the process of learning

Japanese (Gao, 2014, p. 72).

It must be noted that most participants, particularly the older participants, were female. This

might have had some impact on the findings. For instance, female participants who had started learning in

the 1990s were found to have displayed significantly lower willingness to live or work in Japan than

those who started learning Japanese in the 2000s. This could be explained by the fact that most of these

female participants had settled down in life after getting married and having stable careers in China

according to our experience and observations. The interpretation of these findings is constrained by the 
fact that statistical results are correlational and cannot be used to support cause-effect explanations with regard to the learning of Japanese and the participants' intercultural orientations. However, if the statistical results are considered in light of rising popular nationalist sentiments in China, it is thoughtprovoking to see that this group of Japanese language learners displayed overwhelmingly positive intercultural orientations. Moreover, the qualitative data that the participants produced when answering the open-ended questions confirm the critical role that learning a foreign language plays in promoting better intercultural understanding and sustaining goodwill among language learners towards the community of target language speakers (Donitsa-Schmidt et al., 2004; Gardner, 1985; Holmes, 2014). Despite the imbalanced representation of language learners who had started learning Japanese at different times, the shared positive intercultural orientations show that the learning of language does make an important difference in light of the ongoing disputes and the stressful relationship between the two countries (e.g. Holmes, 2014; Sugita-McEown et al., 2014). This is particularly noted in the qualitative answers where they describe how the overall impressions about Japan changed after learning the language and having better knowledge of the country. Those who had been to Japan were also found to have returned with improved impressions, confirming previous research on the impact of educational experiences in Japan on Chinese students (e.g. Yun \& Kibber, 2012). The learning of language, together with improved understanding of the target-language speakers and communities, fosters grass roots diplomacy that can effectively promote intercultural dialogues and counter balance the popular nationalist sentiments (e.g. Holmes, 2014). 


\section{Conclusion}

The inquiry was motivated by the researchers' concern that Japanese language learners' intercultural orientations might have worsened in the last three decades due to the increased tensions between China and Japan (e.g. Cui, 2012; Reilly, 2014). The positive intercultural orientations of the participants testify the strength of motivation underlying the participants' efforts to learn Japanese language as well as the country's culture and people. It must be noted that most participants were current students in universities and the inquiry included a relatively small number of participants who had started learning Japanese much earlier. Most of these early Japanese language learners are Japanese language teachers and employees of Japanese companies in China, especially those who had started learning Japanese in the 1980s and 1990s. While their presence might have weakened the comparability of intercultural orientations of the participants, they confirm that in-depth, meaningful engagement with Japanese people can profoundly mediate intercultural orientations (e.g. Donitsa-Schmidt et al., 2004; Gardner, 1985).

However, the inquiry did identify a very small number of participants whose impressions of Japan had worsened, reflecting that the ongoing disputes between the two countries do have some minor bearing on the participants' intercultural orientations, which may undermine the motivation to learn the language (e.g. Cui, 2012; Reilly, 2014; Sinkkonen, 2013). It must be noted that these participants had never been to Japan and nor do they intend to visit Japan. Nevertheless, this still means that it is absolutely necessary for Japanese language educators to nurture "intercultural competence" to develop better cross-cultural understandings (Gao, 2014, p.73). In light of the tensions between the two countries, 
we suggest that future research should further explore how the promotion of intercultural competence and intercultural citizenship can be integrated in Japanese language education so that the impact of rising nationalism on mutual exchanges could be neutralised (e.g. Donitsa-Schmidt, Inbar \& Shohamy, 2004; Holmes, 2014; Yun \& Kibber, 2012). It is also important for researchers to explore how the learning of languages may help promote better understanding across different cultures and countries so that disastrous conflicts can be avoided (e.g. Holmes, 2014; Yashima, 2002).

\section{References}

Ching, L. (2012). "Japanese devils": The conditions and limits of anti-Japanism in China. Cultural Studies, 26, 710-722.

Cui, S. (2012). Problems of nationalism and historical memory in China's relations with Japan. Journal of Historical Sociology, 25,199-222.

Donitsa-Schmidt, S., Inbar, O., \& Shohamy, E. (2004). The effects of teaching spoken Arabic on students' attitudes and motivation in Israel. The Modern Language Journal, 88 (2), 217-228.

Dörnyei, Z. (2005). The psychology of the language learner: Individual differences in second language acquisition. Mahwah, NJ: Lawrence Erlbaum.

Dörnyei, Z., \& Ushioda, E. (2009). Motivation, language identity and the L2 self. Bristol: Multilingual Matters.

Gao, Y. (2014). Faithful imitator, legitimate speaker, playful creator and dialogical communicator: Shift in English learners' identity prototypes. Language and Intercultural Communication, 14(1), 5975.

Gardner, D. (1985). Social psychology and second language learning: The role of attitudes and motivation. London: Edward Arnold. 
Holmes, P. (2014). Intercultural dialogue: Challenges to theory, practice and research. Language and Intercultural Communication, 14(1), 1-6.

Humphreys, G., \& Miyazoe-Wong, Y. (2007). “So what is the appeal?” The Phenomenon of Japanese as a foreign language in Hong Kong. Journal of Multilingual and Multicultural Development, 28 (6), 468-483.

Kim, Y.Y. (2006). From ethnic to interethnic: The case for identity adaptation and transformation. Journal of Language and Social Psychology, 25, 283-300.

Lin, W. (2013, June $20^{\text {th }}$ ). 叫停抗日神剧 限制过度娱乐化(Stop all these anti-Japanese war TV dramas). The Asashi Shinbun (Chinese edition) Retrieved from http://asahichinese.com/article/china taiwan/AJ201306200052

Patton, M. Q. (1990). Qualitative evaluation and research methods ( $2^{\text {nd }}$ ed.). Newbury Park, CA: Sage Publications.

Reilly, J. (2014). A wave to worry about? Public opinion, foreign policy and China's anti-Japan protests. Journal of Contemporary China, 23(86), 197-215.

Ryan, S. (2006). Language learning motivation within the context of globalisation: An L2 self within an imagined global community. Critical Inquiry in Language Studies, 3(1), 23-45.

Sinkkonen, S. (2013). Nationalism, patriotism and foreign policy attitudes among Chinese university students. The China Quarterly, 216,1045-1063.

Sneider, D. (2013). Textbooks and patriotic education: Wartime memory formation in China and Japan. Asia-Pacific Review, 20, 35-54.

Sugita-McEown, M., Noels, K. A., \& K. Saumure (2014). Students' self-determined and integrative orientations and teachers' motivational support in a Japanese as a foreign language context. System, 45, 227-241.

Tang, W., \& Darr, B. (2012). Chinese nationalism and its political and social origins. Journal of Contemporary China, 21(77), 811-826. 
Tiezzi, S. (2015, January $28^{\text {th }}$ ), China's military parade: A warning to Japan and the US. The Diplomat. Retrieved from http://thediplomat.com/2015/01/chinas-military-parade-a-warning-to-japan-andthe-us/.

Wilson, R. (2013). Another language is another soul. Language and Intercultural Communication, 13(3), 298-309.

Yashima, T. (2002). Willingness to communicate in a second language: The Japanese EFL context. The Modern Language Journal, 86, 54-66.

Yashima, T., \& Zenuk-Nishide, L. (2008). The impact of learning contexts on proficiency, attitudes, and L2 communication: Creating an imagined international community. System, 36, 566-585.

Yun, S., \& Kibber, K. (2012). The strategic values and communicative actions of Chinese students for sociological Korean public diplomacy. International Journal of Strategic Communication, 6, 77-92,

Zhao, S. (1998). A state-led nationalism: The patriotic education campaign in post-Tiananmen China Communist and Post-Communist Studies, 31, 287-302. 
2

Table 1

The participants $(n=665)$

\begin{tabular}{|l|l|l|}
\hline Information & Specifications & Number \\
\hline \multirow{4}{*}{ 1. Gender } & Male & 134 \\
\cline { 2 - 3 } & Female & 522 \\
\cline { 2 - 3 } learning & Unspecified & 9 \\
\hline \multirow{5}{*}{ 3. Years of Japanese learning } & In the 1980s & 40 \\
\cline { 2 - 3 } & In the 1990s & 61 \\
\cline { 2 - 3 } & $2000-2005$ & 33 \\
\cline { 2 - 3 } & $2006-2010$ & 91 \\
\cline { 2 - 3 } & 2011 onwards & 415 \\
\cline { 2 - 3 } & Unspecified & 15 \\
\hline 1. Occupationing Japanese & $1-2$ years & 342 \\
\cline { 2 - 3 } & $2-5$ years & 162 \\
\cline { 2 - 3 } & Over 5 years & 151 \\
\hline \multirow{5}{*}{ 5. Visits to Japan } & Japanese major university students & 429 \\
\cline { 2 - 3 } & Japanese language teachers & 69 \\
\cline { 2 - 3 } & Non-Japanese major university students & 74 \\
\cline { 2 - 3 } & Employees of Japanese companies & 40 \\
\cline { 2 - 3 } & Employees of non-Japanese companies & 38 \\
\cline { 2 - 3 } & Others & 8 \\
\cline { 2 - 3 } & Unspecified & 782 \\
\hline & Never been to Japan & 69 \\
\cline { 2 - 3 } & Once & 32 \\
\cline { 2 - 3 } & More than once & 482 \\
\cline { 2 - 3 } & Unspecified & 82 \\
\hline
\end{tabular}


Table 2

Intercultural orientation

\begin{tabular}{|c|c|c|c|c|}
\hline Items & Factor 1 & Factor 2 & Factor 3 & Factor 4 \\
\hline \multicolumn{5}{|c|}{ Dimension 1: Intercultural exchange and understanding as reasons to learn Japanese } \\
\hline $\begin{array}{l}\text { Learning Japanese helps me understand Japan } \\
\text { better. }\end{array}$ & .845 & .239 & .238 & \\
\hline $\begin{array}{l}\text { Learning Japanese helps me understand } \\
\text { Japanese better }\end{array}$ & .830 & .283 & .244 & \\
\hline $\begin{array}{l}\text { Learning Japanese helps me better appreciate } \\
\text { Japanese culture }\end{array}$ & .692 & .249 & .169 & .260 \\
\hline $\begin{array}{l}\text { Learning Japanese makes it easier for me to } \\
\text { travel to Japan (for studies, sightseeing, visit } \\
\text { friend or settlement) }\end{array}$ & .653 & .275 & .100 & .344 \\
\hline $\begin{array}{l}\text { Learning Japanese makes it easier for me to } \\
\text { participate in activities organized by Japanese } \\
\text { cultural groups }\end{array}$ & .637 & .385 & .148 & .227 \\
\hline \multicolumn{5}{|c|}{ Dimension 2: Readiness to interact with Japanese people } \\
\hline $\begin{array}{l}\text { I welcome Japanese to come to China for } \\
\text { sightseeing, studies or work. }\end{array}$ & .217 & .782 & .140 & .157 \\
\hline $\begin{array}{l}\text { I am willing to participate in voluntary activities } \\
\text { to help Japanese better integrate into my } \\
\text { company, school or community }\end{array}$ & .273 & .675 & .249 & .239 \\
\hline $\begin{array}{l}\text { I am willing to help Japanese who is in need in } \\
\text { public places (such as restaurants or stations) }\end{array}$ & .387 & .661 & .153 & .124 \\
\hline I am willing to make friends with Japanese & .342 & .643 & & .374 \\
\hline $\begin{array}{l}\text { I would interact with Japanese if there is one in } \\
\text { my school or at my workplace. }\end{array}$ & .205 & .641 & .297 & \\
\hline \multicolumn{5}{|c|}{ Dimension 3: Willingness to take up/use Japan-related activities, products and vocations } \\
\hline $\begin{array}{l}\text { I like Japanese cultural products (e.g. movies, } \\
\text { TV dramas, manga or pop music) }\end{array}$ & .261 & & .720 & .223 \\
\hline $\begin{array}{l}\text { I would work in Japanese companies or } \\
\text { organizations }\end{array}$ & & .200 & .679 & .144 \\
\hline $\begin{array}{l}\text { I am interested in attending Japan-related } \\
\text { cultural activities (e.g. popular music concerts } \\
\text { or classic music concerts etc.) }\end{array}$ & .297 & .349 & .545 & .286 \\
\hline I want to visit Japan as a tourist. & .405 & .394 & .455 & \\
\hline \multicolumn{5}{|l|}{ Dimension 4: Interest in Japan-related affairs. } \\
\hline $\begin{array}{l}\text { I pay attention to Japan-related news as well as } \\
\text { various information on issues such as Japanese } \\
\text { economy, society, politics and culture in China. }\end{array}$ & .184 & .169 & & .828 \\
\hline $\begin{array}{l}\text { I pay attention to Japan-related news as well as } \\
\text { various information on issues such as Japanese } \\
\text { economy, society, politics and culture from } \\
\text { Japan. }\end{array}$ & .165 & .235 & .250 & .747 \\
\hline $\begin{array}{l}\text { I participate in online discussions on Japan- } \\
\text { related news, information and topics }\end{array}$ & & & .440 & .677 \\
\hline $\begin{array}{l}\text { I would discuss Japan or what happens in Japan } \\
\text { with my friends or family. }\end{array}$ & .376 & .244 & & .553 \\
\hline
\end{tabular}


Table 3

The participants' starting time for learning Japanese and intercultural orientations

\begin{tabular}{|c|c|c|c|c|c|}
\hline Source & $d f$ & SS & $M S$ & $F$ & $p$ \\
\hline \multirow{2}{*}{$\begin{array}{l}\text { General intercultural orientations } \\
\text { Between groups } \\
\text { Within groups }\end{array}$} & 2 & .21 & .11 & .19 & .83 \\
\hline & 656 & 365.34 & .56 & & \\
\hline \multirow{2}{*}{$\begin{array}{l}\text { Dimension 1('Intercultural Change') } \\
\text { Between groups } \\
\text { Within groups }\end{array}$} & 2 & .39 & .20 & .25 & .78 \\
\hline & 656 & 516.25 & .79 & & \\
\hline \multirow{2}{*}{$\begin{array}{l}\text { Dimension } 2 \text { ('Readiness') } \\
\text { Between groups } \\
\text { Within groups }\end{array}$} & 2 & .67 & .34 & .50 & .61 \\
\hline & 659 & 443.88 & .67 & & \\
\hline \multicolumn{6}{|l|}{ Dimension 3 ('Willingness') } \\
\hline $\begin{array}{l}\text { Between groups } \\
\text { Within groups }\end{array}$ & 659 & 507.16 & .77 & & \\
\hline \multirow{2}{*}{$\begin{array}{l}\text { Dimension } 4 \text { ('Interest') } \\
\text { Between groups } \\
\text { Within groups }\end{array}$} & 2 & 3.90 & 1.95 & 2.33 & .10 \\
\hline & 659 & 550.75 & .84 & & \\
\hline
\end{tabular}

Table 4

Learning circumstances and intercultural orientations

\begin{tabular}{|c|c|c|c|c|c|}
\hline Source & $d f$ & $\mathrm{SS}$ & $M S$ & $F$ & $p$ \\
\hline \multirow{2}{*}{$\begin{array}{l}\text { General posture } \\
\text { Between groups } \\
\text { Within groups }\end{array}$} & 4 & 12.80 & 2.56 & 4.73 & $.000 * * *$ \\
\hline & 652 & 352.97 & .54 & & \\
\hline \multirow{2}{*}{$\begin{array}{l}\text { Dimension } 1 \\
\text { Between groups } \\
\text { Within groups }\end{array}$} & 4 & 14.65 & 2.93 & 3.81 & $.002 * *$ \\
\hline & 652 & 501.29 & .77 & & \\
\hline \multirow{2}{*}{$\begin{array}{l}\text { Dimension } 2 \\
\text { Between groups } \\
\text { Within groups } \\
\end{array}$} & 4 & 12.59 & 2.52 & 3.82 & $.002 * *$ \\
\hline & 655 & 431.44 & .66 & 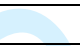 & \\
\hline \multirow{2}{*}{$\begin{array}{l}\text { Dimension } 3 \\
\text { Between groups } \\
\text { Within groups } \\
\end{array}$} & 4 & 21.86 & 4.37 & 5.86 & $.000 * * *$ \\
\hline & 655 & 488.81 & .75 & 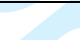 & \\
\hline \multirow{2}{*}{$\begin{array}{l}\text { Dimension } 4 \\
\text { Between groups } \\
\text { Within groups }\end{array}$} & 4 & 11.67 & 2.93 & 3.81 & $.02 *$ \\
\hline & 655 & 541.87 & .77 & & \\
\hline
\end{tabular}


Table 5

Lengths of Japanese learning and intercultural orientations

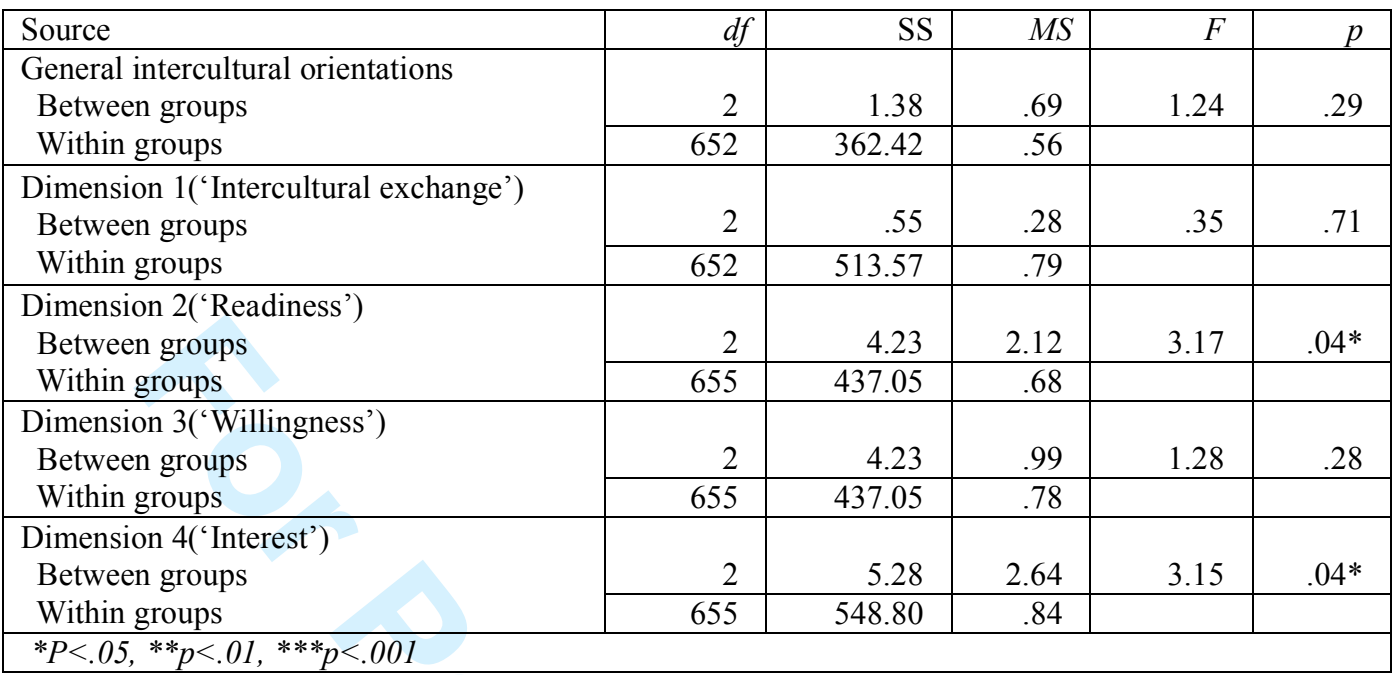

Table 6

Visits to Japan and intercultural orientations

\begin{tabular}{|c|c|c|c|c|c|c|c|}
\hline & 8 & $\mathrm{~N}$ & $\mathrm{M}$ & SD & $\mathrm{t}$ & $d f$ & $p$ \\
\hline \multirow[t]{2}{*}{ General } & 0 visit & 479 & 5.67 & .75 & -2.27 & 627 & $.023 *$ \\
\hline & $>=1$ visit & 150 & 5.83 & .73 & & & \\
\hline \multirow{2}{*}{$\begin{array}{l}\text { Dimension } 1 \\
\text { ('Intercultural exchange') }\end{array}$} & 0 visit & 479 & 5.89 & .89 & -1.71 & 627 & .087 \\
\hline & $>=1$ visit & 150 & 6.03 & .89 & & & \\
\hline \multirow{2}{*}{$\begin{array}{l}\text { Dimension } 2 \\
\text { ('Readiness') }\end{array}$} & 0 visit & 481 & 5.77 & .89 & -2.61 & 629 & $.009 * *$ \\
\hline & $>=1$ visit & 150 & 5.83 & .86 & & & \\
\hline \multirow{2}{*}{$\begin{array}{l}\text { Dimension } 3 \\
\text { ('Willingness') }\end{array}$} & 0 visit & 481 & 5.16 & .94 & -.77 & $256.07^{\mathrm{a}}$ & .440 \\
\hline & $>=1$ visit & 150 & 5.38 & .88 & & & \\
\hline \multirow{2}{*}{$\begin{array}{l}\text { Dimension } 4 \\
\text { ('Interest') }\end{array}$} & 0 visit & 481 & 5.77 & .89 & -2.64 & 629 & $.008 * *$ \\
\hline & $>=1$ visit & 150 & 5.83 & .86 & & & \\
\hline
\end{tabular}

